\title{
Relationship of Illegal Fishing Activities and Sea Resources Conservation Strategies
}

\author{
Nugroho Trisnu Brata ${ }^{1}$ and Didi Pramono ${ }^{2}$ \\ \{trisnu_ntb2015@mail.unnes.ac.id $\left.{ }^{1}, \underline{\text { didipramono@mail.unnes.ac.id }}{ }^{2}\right\}$ \\ ${ }^{1,2}$ Department of Sociology \& Anthropology, Faculty of Social Sciences, \\ Universitas Negeri Semarang, Indonesia
}

\begin{abstract}
Prohibition of using cantrang fishing nets, which are formulated through the Regulation of the Minister of Marine and Fisheries of the Republic of Indonesia No. 02 of 2015 and Minister of Maritime Affairs and Fisheries Regulation No.71 of 2016 caused many protests from fishing communities. This prohibition is based on the fact that cantrang nets are considered to be similar to trawling nets, which can damage the seabed ecosystem. Fishermen fight through various demonstrations. Finally, the government gave temporary permission to use cantrang.The problem in this research is how can the permit for the use of cantrang nets continue during the transition period until later the permit is revoked, there is no turmoil or conflict between fishermen? To overcome this problem, a need assessment step must be done.The long-term goal of this research is to study and make social engineering in terms of capture fisheries' policies to improve the welfare of fishermen through conservation of marine resources. The specific target of this research is to study; (1) strategies for the conservation of marine resources, (2) what needs to be fulfilled in the lives of fishermen, and (3) how to prevent illegal fishing activities from continuing. The method used is a qualitative research method. The researcher conducted an analysis of the primary data sourced from observation, participation observation, and in-depth interviews with the informants. The study was conducted in TasikAgung Village, Rembang Regency, Central Java.
\end{abstract}

Keywords: illegal fishing, cantrang nets, conservation strategies, and marine resources.

\section{Introduction}

The ban on using the cantrang (seine net) to catch fish through the Regulation of Minister of Maritime Affairs and Fisheries No. 02 Year 2015, as well as the Regulation of Minister of Maritime Affairs and Fisheries No.71 Year 2016 has caused many protests from the fisherman community. The ground for this prohibition is because cantrangis considered similar to trawlnet, in which its operation can undermine the marine ecosystem. Fishermen oppose the regulation in various demonstrations. Therefore the government finally has given a temporary permission to use cantrang.

The study problem in this review is how the transition of permission to use cantrang lasting until the revocation of this permit will not arise turbulence and conflict among the fishermen. To address this issue thus a need assessment has to be conducted. This study long-term objective is to review and to make social engineering of fishing policy to prosper the fishermen through the conservation of marine ecosystems. Specific target of this study is to review; (1) the strategies for marine resources conversation, (2) fishermen life needs to be satisfied, and (3) how to prevent the illegal fishingperpetrators continuing their activities. This study used qualitative research method. The writer conducted analysis of primary data sourced from 
observation, participation in observation, and in-depth interviews with the informants. The study was carried out in Tasik Agung Village, Rembang Regency, Central Java.

\section{Research Method}

The methods used in this study were observation, interviews, survey questionnaires, with a descriptive qualitative approach. The research subjects were the fisherman, and the object in this study was the learning of fisherman and illegal fishing activities. The data use triangulation techniques, and the use descriptive qualitative techniques as the analysis techniques.

\section{Result and Discussion}

\subsection{Strategies for Marine Resources Conservation}

According to the government, if the ecosystem is damaged, namely the habitat for the growing of both coral reef as well as small fishes caught in the cantrang net, thence it will threaten the continuity of marine ecosystem. The damage of the ecosystem will lead to a domino effect on the sea food sovereignty, the wiped out of biodiversity resources, as well as the life assurance of the fishermen.

Marine resources conservation needs to be performed on the short and long term so that the marine resources, mainly fish, shrimp, squid, etc. still can be adequately available. One of ways to perform this conservation of marine resources is by stopping to catch fish by means of destructive fishing tools like trawl net and its derivative cantrang net. Both of these fishing tools are damaging the sea biota since they netted and sweep all kinds of fish, whether the adult and young ones, the coral reefs as the habitat of the fish, and other marine biota serves as other fish source of food. The young fish caught leads to the scarcity or even the vanished of adult fish ready for consumption. It also has impacts on the ecosystem as the habitat of the fish to grow and the food source for other fish that in turn will cause to the fish extinction.

Marine resources conservation also can be done by avoiding the use of explosives and fish poison. Explosive can destroy and kill all marine biota and coral reefs as the fish habitat and food source. Similarly, fish poison will kill all the sea biota. Mangrove planting and conservation along the sea shore also can be one of these marine resources conservation efforts. By doing so, the fish is able to find their food in the mangrove and make it as the marine ecosystem that guarantees the sustainability of marine biota existence.

\subsection{Fishermen Living Needs}

Fishermen are frequently assumed as an independent community group which means that when carrying out their livelihood activities, they do not need to plant, take care, and harvest their crops. Fishermen only need to catch fish that grow and proliferate naturally in the sea. If they want to eat fish, they just need to catch them without having to breed or farm them first. It is similar to the forest villagers who are able to pick the fruits from the trees or root tubers, without having to plant and grow them first.

On the other hand, in the monetary economics, it is not only about food and consumption. There are other living needs that have to be satisfied by the fishermen, i.e.need for shelter (house), need for clothing, healthy life guarantee (healthcare), access to technology and fishing tools, 
need for boat fuels, free from debt entanglement from the middlemen, and the guarantee of their fish catch sales. These fishermen living needs, especially the living needs of those work as ship or boat crews or sailors, are frequently unfulfilled by their work outcomes. Fishermen have ships, but the employers are benefited more due to their capital accumulation so that they obtain more income from the fishermen outcomes.

\subsection{Illegal Fishing Activities}

Indonesia actually has abundant wealth of maritime natural resources, however they unfortunately have not been optimally exploited to improve people's welfare. One of obstacles in optimizing the maritime resources is the existence of illegal fishingor the fish catching activities that are not in compliance with the applied regulations. The use of cantrang net is one of examples for this illegal fishingactivity commonly found and practiced in the north coast of Java Island by domestic fishermen. This illegal fishing phenomenon is also practiced by foreign fishermen in the Indonesian territorial waters caught by the Indonesian maritime authorities, which then their ships are sunk by being burnt or blown up [1].

Forms of illegal fishing activities are as follows. Illegal fishing activities commonly found in Indonesia are; the use of prohibited fishing tool since they have destructive impacts on the environment and destroy the young fish; the use of fishing vessels that exceed 150 gross tons of weight as applied by the Indonesian government regulations; and the foreign-flagged vessels operating in the Indonesian territorial waters. Those are the old models of illegal fishing. According to Susi Pudjiastuti [2], now comes the "new model" of illegal fishing, i.e. foreign investors finance the local fishermen to get the permission to catch fish in the Indonesian territorial waters. The government prohibiting foreign investment in the fishery sector and limiting the maximum vessel size is $150 \mathrm{GT}$ (Gross Tons). After the foreign vessels being caught and drowned by the government of Indonesia due to their illegal fishing activities, theyswitch into investors and make domestic fishermen into foreign investor's agents. So far, no illegal fishing activities by domestic vessels or owned by Indonesian fishermen been drowned, however there have been a lot of foreign vessels caught and drowned by the Indonesian authorities. According to a fisherman of Juwana, Central Java, there was an investor from Taiwan that gave investment to fishermen in Batang and Juwana in order to get any ship license or permit and they were offered with profit sharing of 6 percent. So, the permission will be on behalf of domestic fishermen but the owner and operator is foreign investor.

The ship of Indonesian Navy, namely KRI Kapitan Patimura, captured 5 Thailand-flagged fishing vessels consisted of 62 crew members. The vessel was captured while doing illegal fishing Pejantan waters of Riau Islands. The fishing vessels used trawl, fishing tool banned in Indonesia, and it did not have the permission to catch fish in the Indonesian territorial waters. One of the Thai fishermenSompong (28 years old) said that they often fished in the territorial waters of Malaysia and Indonesia since they have more fish than the waters in Thailand. The fish then sold in Malaysia [3]. Illegal fishing practices returned vividly in Bitung, North Sulawesi. The fish of illegal fishing activities were stored in the foreign-owned fish hauling through transshipment in the middle of the sea. And then the fish were sent to a port in General Santos, Cotabato Province, South Philippines [4].

The particular market to sell various kinds of fish from illegal fishing activities is usually located outside Indonesia, namely, among others, the Philippines, China, Malaysia or Thailand. In April 2015, at the time when the author was in the field research in Tawau Malaysia, an informant revealed that since Indonesian government has intensively caught and drowned foreign illegal fishing vessels thus the impact is the lack of fish supply in Tawau Malaysia. 
During previous times, the fish market near the Tawau port abundantly overflew with fish supply from Indonesia, and those were the results of illegal fishing. It was also true when the author conducted observation in the fish market of Tawau Sabah pada on 10 July 2019 where the market was not so crowded.

\subsection{Stop Illegal Fishing}

The ban on the use of cantrang net effectively put in place since January 2018 has been seen as a threat by the fishermen community, both the workers and the employers as the ship owners. Without cantrangnet they cannot work optimally in catching fish as the source of their livelihoods.

Fishermen feel disadvantaged from the prohibition to use the cantrang net as initiated by the government, even though the real reason for it is to protect the continuity of fishermen livelihood by means of more eco-friendly technology to catch fish. Fishermen as a part of marginal groups have not protested by, for example, submitting legal claim. The fishermen show their typical resistance as a marginal group by doing demonstrations and sabotage (blocking the road). However, when their demands do not get serious attention from the government, they explode into national demonstration directly piercing to the capital city of Jakarta, i.e. held in the National Monument of Monas that located close to the Istana Negara (State Palace). As stated by [5] for those who are as marginal, poverty accompanies with uncertainty is more painful and explosive than merely poverty. In this case, poverty among fishermen coupled with uncertainty in the legality of working by using cantrang had triggered the arise of big demonstration on last 18 January 2018.

In the future, cantrang net is banned. However, the fishermen community feel relieved as they are still able to go to the sea and catch fish by using cantrangwithout the anxiety of being stigmatized as illegal fishing perpetrators. The result for doing illegal fishing is arrested by the government authorities up to the sunk of their fishing vessels. Even though this permit is only temporary in nature, but still the problem of satisfying living need of the fishermen can be solved in the short therm.

As solution needs to be found to the phenomenon of the ban of the use of cantrang net and the eradication of illegal fishing activities that have impacted on the decreasing number of fish stealing practices and the abundant fish breeding. First, the government needs to give empowerment to the fishermen and domestic fishery business people. Domestic fishermen have to adhere to the operational rules for fishing and need to be encouraged to be able to fulfill the fish supply to the fish processing industries. The fish processing industries should have ability and internal competitiveness that definitely needs to be supported by bank financing. Second, the government needs to impel the development of domestic industry in the fish processing sector. Momentum for the capture and the drowning campaigns of foreign illegal fishing vessels can be seen as an opportunity for the national fishery business people to improve and develop fishing industry in Indonesia. Third, marketing facilities for fish processed products both in domestic and international markets. The government needs to facilitate the creation of market opportunity for marketing the fish processed product industry.

To put it in another way, domestic investments should be stimulated to enter these fish production and processing areas. Those investments can be in forms of changing the banned fishing net into the one allowed by the government, providing fish refrigerator on the ship, up to building fish processing plants. 


\section{Conclusion}

Strateges of marine resources conservation can be done through the policy on banning the use of cantrang net, explosives, and fish poisons. All these fishing methods determine and destroying the marine ecosystem. This policy is long term in its dimension regarding marine resources conservation. However, in the short term, there have been many resistances from the fishermen community. Fishermen who are accustomed to instant ways will have difficulties dealing with new habit, catching fish without cantrang, explosives, and fish poisons. Persuasive efforts have to be done to the fishermen community so that this public policy can run well.

Fisherman's living needs are not only about matters of clothing, food, and shelter. Include in them are healthcare assurance, access to technology and fishing tools, boat or ship fuel needs, free from debt entanglement of the middleman, guarantee for selling the fish they cats, and certainty and legality in using certain fishing tools.

Strategies in dealing with illegal fishing is currently implemented intensively by the Ministry of Marine Affairs and Fisheries through the capture and the drowning of illegal fishing vessels. Alternative solution that can be proposed here encompasses the empowerment of domestic fishermen, development of domestic fish processing industries, and marketing facilities to the fish processed products both in the domestic and international markets.

\section{Acknowledgement}

The author would like to express gratitude to the the Faculty of Social Science in Universitas Negeri Semarang that has granted fund through skim DIPA FIS UNNES 2019 to the execution of this study.

\section{References}

[1] N. \& D. P. Brata, "The Ban of The Use of CantrangFish Net, Illegal Fishing, and Ship Sinking in Indonesia," 2018.

[2] Kompas, "Modus Baru Perikanan Ilegal Merebak," 4 februari 2016, 2016. .

[3] Kompas, "Lima Kapal Asing Ditangkap, Semua Awak dari Thailand, Ikan Curian Dijual di Malaysia," 2 Mei 2015. .

[4] Kompas, "Praktik Perikanan Ilegal Marak Lagi, Ikan Dibawa ke Filipina," 28 September 2016. .

[5] J. Scott, Moral Ekonomi Petani Pergolakan dan Subsistensi di Asia Tenggara. 1994. 